DIÁLOGO DE POETAS

\title{
II
}

La noche aterrada de sí misma, sobrecogida de pavor espanto, nos vigila, desde el interno espacio de esa piedra sonora: el corazón, y en la espesura, rumor sordo, febril que retumba en sienes las venas, un ala, los vuelos de una falda, el tacto terciopelo, fruto nuevo, resplandor en las selvas del delirio, es un viento, un solar, el origen, el ritmo.

\section{NOSTALGIA DE ARRECIFES}

(Hay una luz de agave para los siglos y eterna vigilia marina: Saint-John Perse)

No hay piélago que lime caracolas ni oleaje que fatigue persistente la estéril quilla de un galeón fantasma, ni violencia de vendaval marino que carcoma un bauprés o decapite un mascarón de proa, derrumbe en resabios salinos el duro maderamen

(vientos del Sur-barreno impostergable).

No hay humedad alada amasando, en pátina y orín, el metal inútilmente trabajado en la fragua. No hay río ni lengua vegetal que someta el rencor de viva roca, 


\section{DIÁLOGO DE POETAS}

ni ritmo ni creciente

en la caricia al filo de la grieta

al otorgar su carga de misterio

y sombra en tierra herida,

no hay soplido terco

que sorprenda la forma oculta en mármol

(vientos alisios escalpelo tenaz).

No hay sol que incendie las arenas

e invente galerías-brazos-raíces

dedos crispados en el latido

nuevo de renovada greda.

No hay intervalos de luz

entre cortezas blanquecinas;

no hay nido ni panal ni comisura

donde sucumba la simiente,

élitro arcilla que abra, alumbre el pan,

como tampoco hay corazón de miel en el agave,

ni poderosa flor que lo embellezca

en su aniquilamiento, ni punta en hoja azul por alojarse

en el pecho del ciervo

o bien que sirva en el telar arcaico (Noto: dios del viento del sur).

Se acabó el espanto, amigo;

desvaneciose la saudade

justo al umbral de condenada puerta, terminaron los días de la Quimera, zozobró la nave cargada de estulticia que surcaba las sirtes imposibles.

Escila, Caribdis devoráronse mutuamente el pétreo corazón. 
Y Polvo es ya la flor marchita agobiada cabe la amarillenta, indescifrable tipografía del libro aquél:

apolillado, sacro, deslomado, viejo

el acto labrado declinó

su antigua majestad y su prestigio

(la inmundicia corroe - dueña absoluta-

sillares, corredores-adoquín mancillado).

Hoy,

ya la luna no desvela a la bestia, duermen en santa paz la hetaira, la sibila, el enamorado, el ladrón y la bruja.

Al callejón no cobija el embozo, no existe más

el abrazo al abrigo de la sombra el Árbol.

El camastro sudario de ramera

casta-hermosa-moza-púber también es ido.

Ha sido roto el maleficio, expulsado el Minotauro del sueño, de la vigilia el numen, del fuego fatuo el vacilante espíritu.

No hay nadie que se llame Nadie que inquiera a Andrómeda y busque en Tauro el rumbo de la noche. No hay puñal ni alfanje en cinto de corsario, no hay escudo, montura, herida espada, no hay hugonotes, ....amigo (olor agrio) sin rastro de sangre coagulada ni furtivas lecturas 
DIÁLOGO DE POETAS

de surcos en la mano,

ni lascivas... sonrisas

ni aún, lance de dados,

ni lucha cuerpo a cuerpo ni alabarda

torre de asalto aceite hirviente

honda catapulta y espingarda

ni pies alados sucumbiendo

ni talones vulnerables, amigo venerable.

No hay humo, hermano,

no hay humo de cadáveres robados,

despojados en el amanecer de la batalla, ni lenguajes inversos, torres ennegrecidas

bajo el asedio innoble de las aves de presa, decapitados a galope hundidos

en la noche laberíntica del Tiempo, hendiendo la negrura de la Nada.

¿Qué nos queda oh Señor de la Abyección

y la Molicie?

¿Qué residuo yace al fondo

de la criba en los pozos del alma?

¿Qué suerte de vegetación nos nace?

¿Qué musgo en los muros ruinosos

de incierta historia?

¿Y cuál humos en los infames pantanos

de nuestra eyección aciaga?

Os queda la Ciudad, el coliseo, tal vez, el columbario roto,

la orgía inacabada, alguna notación convencional, la paz del camposanto, un tímido aguafuerte de fin de siglo, un pianoforte, el hastío, el diván, un licor áureo, generoso, suave al paladar. 